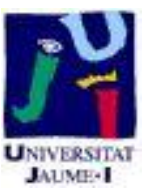

Título artículo / Títol article: Focal Lesions within the ventral striato-pallidum abolish attraction for male chemosignals in female mice

Autores / Autors

Carmen Agustín-Pavón, Fernando Martínez-García, Enrique Lanuza

Revista:

BEHAVIOURAL BRAIN RESEARCH

Versión / Versió:

Postprint del autor

Cita bibliográfica / Cita bibliogràfica (ISO 690):
AGUSTÍN-PAVÓN, Carmen; MARTÍNEZ-GARCÍA, Fernando; LANUZA, Enrique. Focal lesions within the ventral striato-pallidum abolish attraction for male chemosignals in female mice. Behavioural brain research, 2014, vol. 259, p. 292-296. 


\title{
Focal lesions within the ventral striato-pallidum abolish attraction for male chemosignals in female mice
}

\author{
Q \\ a Laboratori de Neuroanatomia Funcional Comparada, Depts. de Biologia Funcional i BiologiaCel-lular, Facultat de CiènciesBiològiques, Universitat de \\ València C/Dr. Moliner, 50, 46100 Burjassot, Spain \\ ${ }^{\mathrm{b}}$ EMBL/CRG Systems Biology Research Unit, Centre for Genomic Regulation and Universitat Pompeu Fabra, 08003 Barcelona, Spain
}

\section{H I G H L I G H T S}

- We lesion the medioventral striato-pallidum (mvStP) in female mice.

- These lesions abolish female mice innate preference for male chemosignals.

- Lesions of the posterolateral striato-pallidum do not affect this preference.

- The mvStP controls intersexual attraction mediated by chemosignals in female mice.

- The mvStP processes the hedonic properties of biological chemical signals.

\section{A R T I C L E I N F O}

\section{Article history:}

Received 18 September 2013

Received in revised form 9 November 2013

Accepted 12 November 2013

Available online xxx

\section{Keywords:}

Islands of Calleja

Olfactory tubercle

Reward

Sexual attraction

Vomeronasal system

\begin{abstract}
A B S T R A C T
In rodents, socio-sexual behaviour is largely mediated by chemosensory cues, some of which are rewarding stimuli. Female mice display an innate attraction towards male chemosignals, dependent on the vomeronasal system. This behaviour likely reflects the hedonic value of sexual chemosignals. The anteromedial aspect of the olfactory tubercle, along with its associated islands of Calleja, receives vomeronasal inputs and sexually-dimorphic vasopressinergic innervation. Thus, we hypothesised that this portion of the ventral striato-pallidum, known to be involved in reward processing, might be important for sexual odorant-guided behaviours. In this study, we demonstrate that lesions of this region, but not of regions in the posterolateral striato-pallidum, abolish the attraction of female mice for male chemosignals, without affecting significantly their preference for a different natural reward (a sucrose solution). These results show that, at least in female mice, the integrity of the anterior aspect of the medioventral striato-pallidum, comprising a portion of the olfactory tubercle and associated islands of Calleja, is necessary for the attraction for male chemosignals. We suggest that this region contributes to the processing of the hedonic properties of biologically significant odorants.
\end{abstract}

(c) 2013 Published by Elsevier B.V.
The ventral striatum is a key centre in the processing of rewarding stimuli [1]. The ventral striatum includes the nucleus accumbens (Acb), the olfactory tubercle $(\mathrm{Tu})$ and several associated structures such as the islands of Calleja (ICj) and the striatal cell bridges (CB), whose striatal or pallidal nature is unclear [2]. Given its olfactory nature, related to the direct input from the main olfactory bulb, the Tu is supposed to encode the hedonic properties of olfactory stimuli [3-6]. The ICj are heterogeneous cell clusters whose function remains poorly understood, although they might also play a role in olfactory processing $[7,8]$.

\footnotetext{
* Corresponding author at: Centre for Genomic Regulation, Systems Biology, C/Dr. Aiguader, 88, 08003 Barcelona, Barcelona, Spain. Tel.: +34963543383; fax: +34963543404

E-mail addresses: m.carmen.agustin@uv.es, carmen.agustin.pavon@gmail.com (C. Agustín-Pavón).
}

The chemosensory amygdala projects to the medial Tu and associated ICj and CB [6], an area we refer to as the medioventral striato-pallidum (mvStP). A striking feature of the mvStP is that it shows sexually dimorphic vasopressinergic innervation [9], suggesting that it is a node in the neural network for socio-sexual behaviour.

Sexual behaviour is largely mediated by olfactory cues in rodents [10]. Female mice are innately attracted by non-volatile male chemosignals $[11,12]$ detected by the vomeronasal system [13]. The pheromone darcin, a major urinary protein, is responsible for female attraction [14]. Male soiled-bedding containing sexual chemosignals [12] or darcin alone [15] induce conditioned place preference in female mice. Similarly, vaginal secretions, containing female sexual chemosignals, induce conditioned place preference in male hamsters [16]. Thus, sexual pheromones are rewarding stimuli that promote the first step of sexual behaviour, namely intersexual attraction. 


\section{A. Medial lesion}

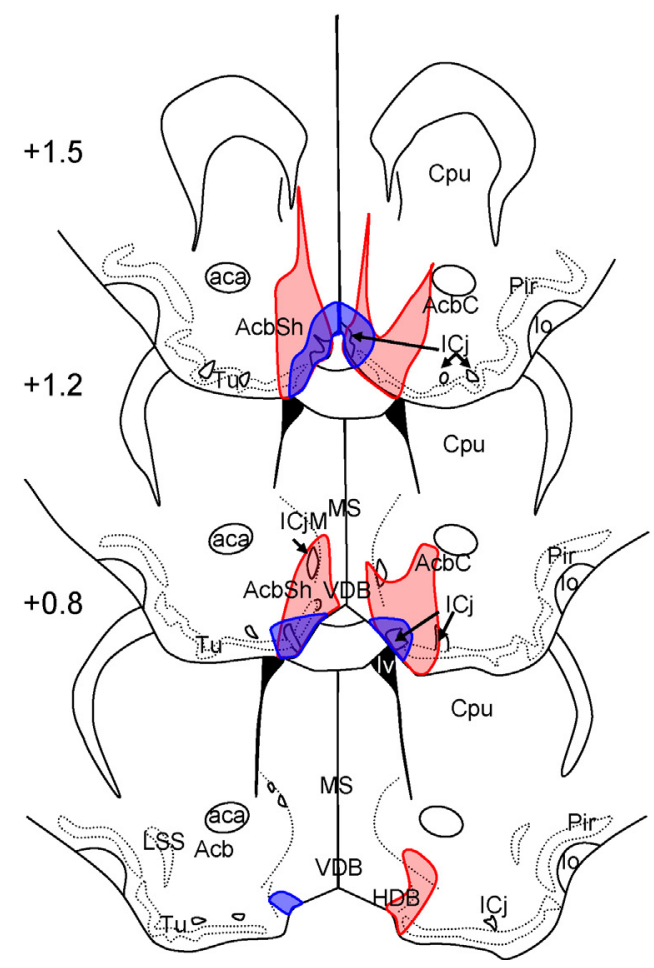

B. Lateral lesion

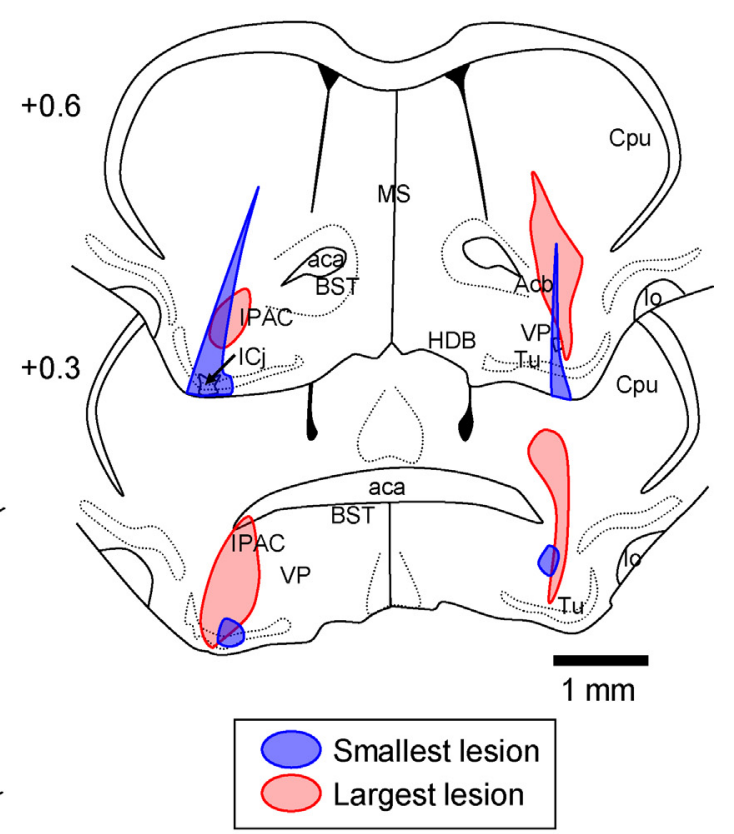

Reward includes at least three components, namely "liking" (hedonia), "wanting" (motivation) and learning [17]. Instrumental paradigms make it possible to study the two last components, but measuring "liking" in non-human animals is not straightforward. One possibility is to investigate the unconditioned responses elicited by rewarding stimuli [18]. Thus, the innate attraction displayed by mice towards sexual chemosignals can be used as a measure of liking $[19,20]$.

In this study, we tested whether the mvStP, including a portion of the medial $\mathrm{Tu}$ and anteromedial $\mathrm{ICj}_{\mathrm{C}}$, might be involved in the innate attraction (or liking) for sexual chemosignals in female mice. To do so, we measured the unconditioned preference for male chemosignals of females bearing electrolytic lesions of medial regions of the ventral striato-pallidum, and compared their effects with control lesions of posterolateral striatopallidum (plStP), which receives scarce inputs from vomeronasal amygdala [6].

We used 51 adult female mice (CD1 strain). To ensure that their preference for male pheromones were innate to reflect liking, we used "chemically-naïve" females [11]. Briefly, pregnant females acquired from Harlan (Barcelona, Spain) were housed in the absence of adult males or male-derived chemicals. Nineteen days after delivery, pups were sexed, males were removed and their female siblings were housed in groups of 4-8 animals, with food and water ad libitum. These females were used from week 9 of age. The innate attraction response is not dependent on hormonal status in "chemically-naïve" females [21], and thus we did not control for this variable.

The animals were treated throughout according to the European Communities Council Directive of November 24th, 1986 $(86 / 609 / \mathrm{EEC})$ and procedures were approved by the Committee of Ethics on Animal Experimentation of the University of València.

Females were randomly assigned to three groups: SHAMoperated $(n=14)$, MEDIAL lesion $(n=27)$ and LATERAL lesion $(n=10)$. For stereotaxic surgery, animals were deeply anaesthetized with sodium pentobarbital $(60 \mathrm{mg} / \mathrm{kg}$ i.p.), and administered atropine $\left(0.4 \mathrm{mg} / \mathrm{kg}_{\wedge}\right.$ i.p. $)$ to prevent cardio-respiratory depression and buprenorphine (Buprex, Schering-Plough; $0.02 \mathrm{mg} / \mathrm{kg}$, s.c.) for analgesia. Mice were placed on a stereotaxic frame (David Kopf Instruments 963-A, Tujunga CA, EE.UU). Coordinates were adjusted from [22]. The experimenter drilled a hole in the skull to insert a stainless steel electrode $(250 \mu \mathrm{m}$ of diameter, Ugo Basile, Varese, Italy). Lesions were performed by passing a constant (negative) current of $0.8 \mathrm{~mA}$ for $15 \mathrm{~s}$. In SHAM surgery the electrode was inserted but no current was applied. An observer unaware of the treatment of the samples performed the post-mortem evaluation of the span of the lesions (Fig. 1, Table 1).Since we were interested in testing the role of the projection from the vomeronasal amygdala to the mvStP, which is especially substantial to the medial ICj [6], we used the volume of these structure as aprioristic criterion for the inclusion of mice in the analysis of the MEDIAL lesion group. The sections of the IC $\mathrm{j}$ between levels Bregma +1.9 and +0.8 , were drawn using a camera lucida, drawings scanned and digital images calibrated and binarized with ImageJ software (NIH). Total volume of the anteromedial $\mathrm{ICj}$ plus the major ICj was estimated for each hemisphere using the Cavallieri method. Animals bearing lesions of at least a $40 \%$ of the volume of the mentioned ICj in each hemisphere and of more than a $50 \%$ of their total volume in both hemispheres, were included in the analysis. Mice showing unilateral $(n=5)$, small or no lesion $(n=6)$, or enlarged ventricles due to a misplacement of the electrode $(n=3)$ were discarded (not 
Table 1

Total volume (right plus left hemisphere) of the lesion in MEDIAL and LATERAL lesion group, and main regions affected by the lesions in each mouse brain. Abbreviations: aca: anterior comissure; AcbC: nucleus accumbens core; AcbSh: nucleus accumbens shell; plAcb: posterolateralaccumbens; vCpu: ventral caudatus-putamen; amICj: anteromedial island of Calleja; ICjM: major island of Calleja; Pir: piriform cortex; mTu: medial olfactory tubercle; ITu: lateral olfactory tubercle; VDB: ventral diagonal band; VP: ventral pallidum; $\wedge$ affected unilaterally.

\begin{tabular}{lll}
\hline Medial lesion Specimen & Volume $\left(\mathrm{mm}^{3}\right)$ & Affected nuclei \\
\hline M1 & 3,1 & amICj, ICjM, mTu, AcbSh \\
M2 & 2,8 & amICj, ICjM, mTu \\
M3 & 1,7 & amICj, ICjM, mTu \\
M4 & 2,9 & amICj, ICjM, mTu, AcbSh \\
M5 & 3,9 & amICj, ICjM, mTu, AcbC, \\
& & AcbSh, aca \\
M6 & 3,3 & amICj, ICjM, mTu, VDB \\
M7 & 1,7 & amICj, mTu, VDB \\
M8 & 4,2 & ICjM, mTu, AcbSh, VDB \\
M9 & 1,5 & amICj, ICjM, mTu \\
Average volume & 2,8 & \\
S.E.M & 0,3 & \\
Lateral lesión Specimen & Volume (mm $\left.{ }^{3}\right)$ & Affected nuclei \\
L1 & 1,2 & plAcb, ITu, VP \\
L2 & 3,9 & plAcb, ITu, VP, vCpu \\
L3 & 2,2 & plAcb, ITu, VP \\
L4 & 3,8 & plAcb, ITu, VP, vCpu \\
L5 & 3,2 & plAcb, ITu, VP \\
L6 & 3,1 & plTu, vCpu, VP \\
L7 & 3,9 & plAcb, ITu, VP, vCpu \\
L8 & 3,3 & plAcb, ITu, VP, vCpu, Pir \\
Average volume & 3,1 & \\
S.E.M & 0,3 & \\
\hline
\end{tabular}

We calculated a preference score as "Time spent in right dish/Total time spent in both dishes". A repeated measures ANOVA with GROUP (SHAM-operated, MEDIAL lesion, LATERAL lesion) as between-subjects factor and TEST (control, male preference test) as within-subjects factor of this score revealed a significant effect of the second order interaction TEST $x \operatorname{GROUP}\left(F_{2,25}=3.66, p=0.04\right)$, a significant TEST effect $\left(F_{2,25}=23.34, p<0.001\right)$ but non-significant effect of the factor GROUP $\left(F_{2,25}=1.88, p=0.17\right)$. Post-hoc pair wise comparisons revealed significant differences between the control and male preference tests both in the SHAM $(p=0.001)$ and in the LATERAL $(p<0.001)$ groups. In contrast, the preference score of the animals of the MEDIAL group did not differ between tests $(p=0.57)$ (Fig. 2A). A Student's $t$-tests comparing the preference score in the male preference test with the chance value $(0.5)$ revealed that both SHAM and LATERAL mice, but not MEDIAL, displayed preference for male chemosignals, $(p<0.001, p=0.018$, and $p=0.78$ respectively) (Fig. $2 \mathrm{~A}$ ). Thus, at least in female mice, the integrity of the mvStP is necessary for the attraction towards male chemosignals.

A one-way ANOVA between groups revealed that groups differed significantly in locomotion $\left(F_{2,25}=4.805, p=0.017\right)$. A SNK post-hoc analysis revealed that the difference was due to significantly higher locomotion in MEDIAL group animals (Fig. 2B). Hyperlocomotion has been shown in rodents upon deletion or downregulation of dopamine D3 receptors, which are highly expressed in the area affected by the medial lesion [23-25]. Interestingly, it was previously suggested that this hyperlocomotion was due to a dysfunctional exploration due an impaired processing of chemosensory cues by Tu and ICj [24].

We find unlikely that lack of attraction for male pheromones observed in MEDIAL-lesioned females derives from increased motor activity. An ANOVA revealed no differences between groups in basal investigatory behaviour in the control test $\left(F_{2,25}=2.070\right.$; $p=0.147$ ) (Fig. 2C). Therefore, lesions of the mvStP slightly enhanced locomotion but had no significant effects on exploratory behaviour of female bedding.

To check whether lesions had specific or general effects on consummatory responses driven by rewarding stimuli, we tested another reward-mediated response, namely sucrose-sweetened $v s$. water preferential intake. One week after the pheromone preference tests, mice were deprived of water (20:00 p.m-8:00 a.m.) and habituated for 2 days for $15 \mathrm{~min}$ ( $8: 00$ a.m. $-13: 00$ a.m) to the test cage $(25 \times 25 \times 30 \mathrm{~cm})$ with two bottles containing water. On the third day, animals were placed again in the test cage with one bottle containing tap water and the other a $5 \%$ sucrose solution, and the licks on each bottle were automatically registered with a lickometer for 15 min (Packwin software, Panlab, Spain).

We calculated the total amount of licks made by the animals during the test from both bottles and the preference score (Licks to the $5 \%$ sucrose solution/Total number of licks). An ANOVA comparing these measures revealed that neither the total number of licks $\left(F_{2,19}=1.09 ; p=0.36\right.$; Fig. 2D $)$ nor the preference score $\left(F_{2,19}=0.23\right.$; $p=0.79$; Fig. 2E) were different between groups. A Student's $t$ tests comparing the pooled preference score with the chance value revealed that, overall, this measure was significantly different from $0.5(p<0.01)$. Thus, in contrast to preference for male chemosignals, the lesions of mvStP did not significantly affect the preference for a sweet solution.

Amygdalo-striatal circuits are crucial for reward processing [26]. The cortical division of the amygdala, including both olfactory and vomeronasal nuclei, sends important projections to the $\mathrm{Tu}$ and ICj [4-6]. Also, scarce input from the medial amygdala reaches the medial region of the $\mathrm{Tu}$ [27]. We have hypothesised that this amygdalo-striatal pathway might underlie the rewarding properties of pheromones $[4,6]$. The present results show that the integrity package SMART 2.5 (Panlab, Cornellà, Spain). Data were analyzed with the SPSS 15.0 software package. 
A
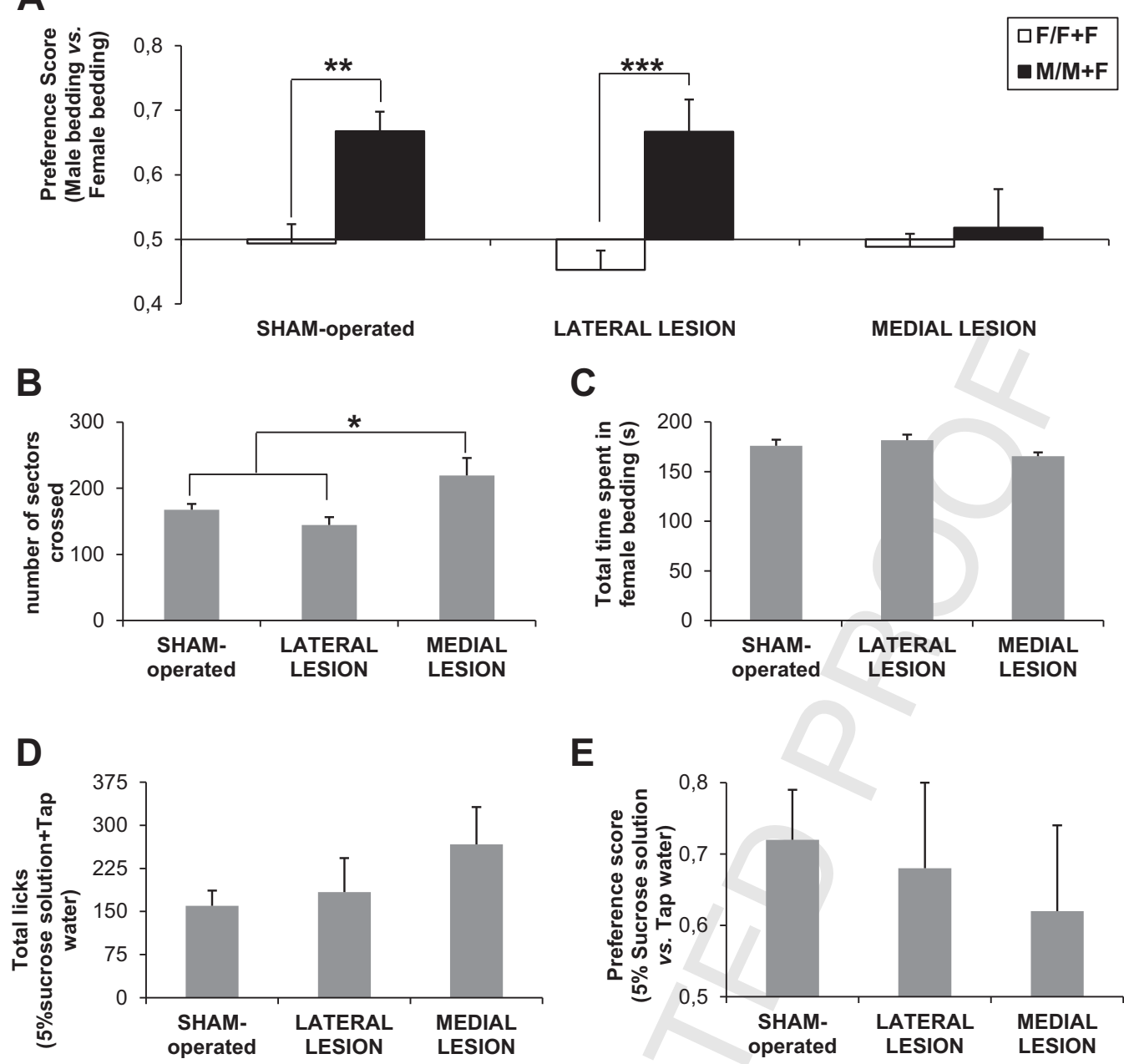

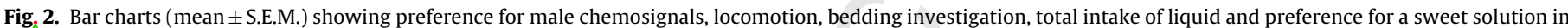
Q2 SHAM-operated, LATERAL and MEDIAL groups. ${ }^{*} p<0.05 ;{ }^{* *} p<0.01 ;{ }^{* * *} p<0.001>$

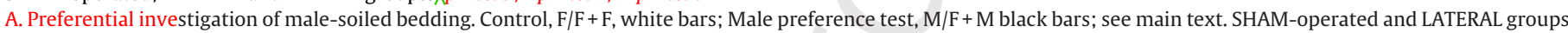
significantly preferred male-soiled bedding in the male preference test, but female mice bearing a MEDIAL lesion did not.

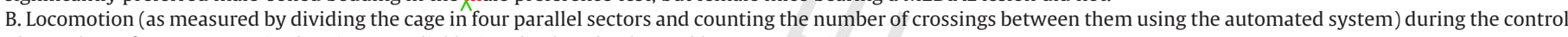
plus male preference test. Mice bearing a medial lesion displayed enhanced locomotor activity.

C. Total time in seconds investigating both dishes in the control $(F+F)$. The surgery did not affect basal chemoinvestigatory behaviour displayed by female mice.

D. Total licks performed during the sucrose preference test. No significant differences were found between groups.

E. Preference for $5 \%$ sucrose solution. (Number of licks performed on the $5 \%$ sucrose solution bottle/Total licks). No differences were found between groups.

Abbreviations: F: female-soiled bedding, M: male-soiled bedding.

of the region targeted by vomeronasal inputs, which we refer to as mvStP, is necessary for the behavioural expression of sexual chemosignals liking in female mice, providing the first functional piece of evidence supporting this hypothesis.

Previous studies showed medio-lateral heterogeneity within the ventral striatum. Rats readily learn to self-administer low concentrations of cocaine in the medial Tu, whereas higher concentrations are needed to achieve self-administration in adjoining structures (medial shell of the Acb and posterolateral Tu [1]). In contrast, dorsolateral regions play an important role in habit formation with increasing experience of the animals with the reward.

Our results parallel these findings, but the distinction found here is likely due to the nature of the attractive chemical signals. Innately attractive chemosignals are detected by the vomeronasal system [13], which targets preferentially the medial regions. With experience, volatile male odorants acquire attractive properties by association with the non-volatile chemosignals [11]. Thus, it is possible that lateral parts of the ventral striato-pallidum play a role in processing volatile odorants in experienced animals, but this suggestion remains to be tested.

The neural network of socio-sexual behaviour [28] includes sexually dimorphic nuclei, such as preoptic area and ventromedial hypothalamus. These nuclei are involved in the control of paracopulatory and copulatory components of sexual behaviour $[29,30]$. We recently showed that an area of the mvStP is targeted by sexually dimorphic vasopressinergic innervations [9]. Based on this, we proposed that this region should be included in the socio-sexual behaviour network. Here, we show that the lesions of the mvStP abolish innate attraction towards sexual chemosignals, which can be regarded as paracopulatory behaviour [21], adding functional evidence to support this proposal.

We acknowledge that the electrolytic lesions do not allow targeting selectively the different components of the ventral striato-pallidal complex. Thus, although medial lesions consistently affected to the ICj and Tu, other structures such as the Acb and VDB were affected in some of the animals (see Table 1). Future studies using more selective methods should investigate the 
contribution of these different nuclei to the observed behaviour. In particular, it would be interesting to explore the role of the ICj. Although roles in processing sex-related odours and/or modulation of reproductive events have been previously suggested [2,8], scarce evidence is available supporting these statements. Interestingly, adult-born neurons incorporate into the ICJ [31], whose number and structure vary with aging [32]. Since adult neurogenesis is essential for olfactory-guided social behaviours [33] and olfactory dysfunction is a feature of aging and neurodegeneration [34], we expect that future studies will shed light about the contribution of this unexplored archipelago to those phenomena.

In conclusion, our data suggest that the mvStP plays a key role in the processing of the hedonic properties of biologically significant chemical signals in the context of socio-sexual and reward-directed behaviour, and defines this region as an important node in mediating sexual attraction of females through male chemosignals. Future work is needed to investigate the contribution of the mvStP to the same behaviour in males, in the response of animals in front of different chemosignals from the ones used here, and the roles of other pathways important for chemical communication.

Finally, it would be interesting to investigate the possibility of a role of this region of the mvStP, and the portions of the amygdala that project to it, in sexual attraction mediated by other sensory modalities [35]. Indeed, human neuroimaging studies reveal significant activation of the amygdala and ventral striatum in view of sexually arousing images [36,37]. It would be also interesting to investigate whether sexual orientation (what gender is sexually arousing) might be influenced by the function of this circuitry [37].

\section{Acknowledgement}

Funded by the Spanish Ministry of Education and Science-FEDER (BFU2007-67912-C02-01/BFI and BFU2010-16656).

\section{References}

[1] Ikemoto S. Dopamine reward circuitry: two projection systems from the ventral midbrain to the nucleus accumbens-olfactory tubercle complex. Brain Res Rev 2007;56:27-78.

[2] Fallon JH, Loughlin SE, Ribak CE. The islands of Calleja complex of rat basal forebrain III. Histochemical evidence for a striatopallidal system. J Comp Neurol 1983;218:91-120.

[3] Wesson DW, Wilson DA. Sniffing out the contributions of the olfactory tubercle to the sense of smell: hedonics, sensory integration, and more? Neurosci biobehav rev 2011;35:655-68.

[4] Ubeda-Banon I, Novejarque A, Mohedano-Moriano A, Pro-Sistiaga P, de la RosaPrieto C, Insausti R. Projections from the posterolateral olfactory amygdala to the ventral striatum: neural basis for reinforcing properties of chemical stimuli. BMC Neurosci 2007;8:103.

[5] Ubeda-Banon I, Novejarque A, Mohedano-Moriano A, Pro-Sistiaga P, Insausti $\mathrm{R}$, Martinez-Garcia F. Vomeronasal inputs to the rodent ventral striatum. Brain Res Bull 2008;75:467-73.

[6] Novejarque A, Gutierrez-Castellanos N, Lanuza E, Martinez-Garcia F. Amygdaloid projections to the ventral striatum in mice: direct and indirect chemosensory inputs to the brain reward system. Front Neuroanat 2011;5:54.

[7] Calleja C. La Región Olfatoria del Cerebro. Madrid: Imprenta y Librería de Nicolás Moya; 1893.

[8] Talbot K, Woolf NJ, Butcher LL. Feline islands of Calleja complex: II. Cholinergic and cholinesterasic features. J Comp Neurol 1988;275:580-603.

[9] Otero-Garcia M, Martin-Sanchez A, Fortes-Marco L, Martinez-Ricos J, AgustinPavon C, Lanuza E. Extending the socio-sexual brain: arginine-vasopressin immunoreactive circuits in the telencephalon of mice. Brain Struct Funct 2013.

[10] Wyatt TD. Pheromones and animal behaviour. Cambridge University Press; 2003.
[11] Moncho-Bogani J, Lanuza E, Hernandez A, Novejarque A, Martinez-Garcia F. Attractive properties of sexual pheromones in mice: innate or learned. Physiol Behav 2002;77:167-76.

[12] Martinez-Ricos J, Agustin-Pavon C, Lanuza E, Martinez-Garcia F, Intraspecific communication through chemical signals in female mice: reinforcing properties of involatile male sexual pheromones. Chem Senses 2007;32:139-48.

[13] Martinez-Ricos J, Agustin-Pavon C, Lanuza E, Martinez-Garcia F. Role of the vomeronasal system in intersexual attraction in female mice. Neuroscience 2008;153:383-95.

[14] Roberts SA, Simpson DM, Armstrong SD, Davidson AJ, Robertson DH, McLean L. Darcin: a male pheromone that stimulates female memory and sexual attraction to an individual male's odour. BMC Biol 2013;8:75.

[15] Roberts SA, Davidson AJ, McLean L, Beynon RJ, Hurst JL. Pheromonal induction of spatial learning in mice. Science 2012;338:1462-5.

[16] Bell MR, Meerts SH, Sisk CL. Male Syrian hamsters demonstrate a conditioned place preference for sexual behavior and female chemosensory stimuli. Horm Behav 2010;58:410-4.

[17] Berridge KC, Robinson TE. Parsing reward. Trends Neurosci 2003;26:507-13.

[18] Berridge KC. Measuring hedonic impact in animals and infants: microstructure of affective taste reactivity patterns. Neurosci Biobehav Rev 2000;24:173-98.

[19] Agustin-Pavon C, Martinez-Ricos J, Martinez-Garcia F, Lanuza E. Effects of dopaminergic drugs on innate pheromone-mediated reward in female mice: a new case of dopamine-independent liking. Behav Neurosci 2007;121:920-32.

[20] Malkesman O, Scattoni ML, Paredes D, Tragon T, Pearson B, Shaltiel G. The female urine sniffing test: a novel approach for assessing reward-seeking behavior in rodents. Biol Psychiatry 2010;67:864-71.

[21] Moncho-Bogani J, Lanuza E, Lorente MJ, Martinez-Garcia F. Attraction to male pheromones and sexual behaviour show different regulatory mechanisms in female mice. Physiol Behav 2004;81:427-34.

[22] Paxinos G, Franklin KBJ. The Mouse Brain in Stereotaxic Coordinates. 2nd ed. San Diego: Elsevier; 2001.

[23] Accili D, Fishburn CS, Drago J, Steiner H, Lachowicz JE, Park BH. A targeted mutation of the D3 dopamine receptor gene is associated with hyperactivity in mice. Proc Natl Acad Sci USA 1996;93:1945-9.

[24] Xu M, Koeltzow TE, Santiago GT, Moratalla R, Cooper DC, Hu XT. Dopamine D3 receptor mutant mice exhibit increased behavioral sensitivity to concurrent stimulation of D1 and D2 receptors. Neuron 1997;19:837-48.

[25] Menalled LB, Dziewczapolski G, Garcia MC, Rubinstein M, Gershanik OS. D3 receptor knockdown through antisense oligonucleotide administration supports its inhibitory role in locomotion. Neuroreport 1999;10:3131-6.

[26] Everitt BJ, Parkinson JA, Olmstead MC, Arroyo M, Robledo Pि, Robbins TW. Associative processes in addiction and reward: the role of amygdala-ventral striatal subsystems. Ann NY Acad Sci 1999;877:412-38.

[27] Pardo-Bellver C, Cadiz-Moretti B, Novejarque A, Martinez-Garcia F, Lanuza E. Differential efferent projections of the anterior, posteroventral, and posterodorsal subdivisions of the medial amygdala in mice. Front Neuroanat 2012;6:33.

[28] Newman SW. The medial extended amygdala in male reproductive behavior. A node in the mammalian social behavior network. Ann NY Acad Sci 1999;877:242-57.

[29] Hull EM, Meisel RL, Sachs BD. Male sexual behavior. In: Pfaff DW, Arnold AP, Etgen AM, Fahrbach SE, Rubin RT, editors. Hormones, brain and behavior. New York: Academic Press; 2002. p. 1-137.

[30] Blaustein JD, Erksine MS. Feminine sexual behavior: cellular integration of hormonal and afferent information in the rodent brain. In: Pfaff DW, Arnold AP. Etgen AM, Fahrbach SE, Rubin RT, editors. Hormones, brain and behavior. New York: Academic Press; 2002. p. 139-214.

[31] De Marchis S, Fasolo A, Puche AC. Subventricular zone-derived neuronal progenitors migrate into the subcortical forebrain of postnatal mice. Comp Neurol 2004:476:290-300.

[32] Adjei S, Houck AL, Ma K, Wesson DW. Age-dependent alterations in the number, volume, and localization of islands of Calleja within the olfactory tubercle. Neurobiol Aging 2013;34:2676-82.

[33] Gheusi G, Ortega-Perez I, Murray K, Lledo PM. A niche for adult neurogenesis in social behavior. Behav Brain Res 2009;200:315-22.

[34] Gallarda BW, Lledo PM. Adult neurogenesis in the olfactory system and neurodegenerative disease. Curr Mol Med 2012;12:1253-60.

[35] Wesson DW, Wilson DA. Smelling sounds: olfactory-auditory sensory convergence in the olfactory tubercle. J Neurosci 2010;30:3013-21.

[36] Hamann S, Herman RA, Nolan CL, Wallen K. Men and women differ in amygdala response to visual sexual stimuli. Nat Neurosci 2004;7:411L 416.

[37] Kagerer S, Klucken T, Wehrum S, Zimmermann M, Schienle A, Walter B, et al. Neural activation toward erotic stimuli in homosexual and heterosexual males. Sex Med 2011;8:3132-43. 